\title{
The rediscovery of the Madagascar Red Owl Tyto soumagnei (Grandidier 1878) in north-eastern Madagascar
}

\author{
DOMINIQUE HALLEUX and STEVEN M. GOODMAN
}

\section{Summary}

The Madagascar Red Owl, known from the eastern rainforest of central Madagascar by a few specimens collected in the nineteenth and early twentieth century and one sight record in 1973, was rediscovered in late July 1993 in north-eastern Madagascar. An adult bird, held in captivity for approximately one year, was located in the town of Andapa. According to the owner, the owl had been obtained south-west of Andapa, near the village of Antanamangotroka, in a forested area connected to the Réserve Spéciale $\mathrm{d}^{\prime}$ Anjanaharibe-Sud, and at about $800 \mathrm{~m}$ above sea-level. This record expands the known geographic range of this species and provides the first documentation of its continued existence in over 20 years.

La Chouette de Soumagne, connue de la forêt pluviale orientale du Domaine du Centre de Madagascar à travers quelques spécimens collectés au 19ème siècle et début du zoème siècle et d'après une observation en 1973, a été redécouverte à la fin du mois de juillet 1993 au nord-est de Madagascar. Un individu adulte, qui venait de passer plus d'un an en captivité, a été découvert dans la ville d'Andapa. D'après la personne qui détenait l'animal, la chouette avait été capturée au sud-ouest d'Andapa, près du village d'Antanamangotroka, au sein d'une zone forestière connectée avec la Réserve Spéciale d'Anjanaharibe-Sud, à une altitude d'environ $800 \mathrm{~m}$ au-dessus du niveau de la mer. Cette nouvelle donnée constitue une expansion significative de l'aire de distribution de cette espèce et apporte la preuve de la survie de cette espèce endémique qui n'avait pas été observée depuis plus de 20 ans.

\section{Introduction and known geographic range}

The Madagascar Red Owl Tyto soumagnei is considered to be one of the rarest endemic bird species of Madagascar (Langrand 1990). After this species's original description (Grandidier 1878), there are few records of it. $T$. soumagnei is known from 10 existing specimens collected between 1876 and 1934 at localities in the central portion of the eastern rainforest. (Measurements of examined specimens are presented in Table 1.) Records and reports of the Madagascar Red Owl include (arranged in order from north to south):

Masoala Peninsula Milon et al. (1973) reported this species from the Masoala Peninsula (centred at $15^{\circ} 30^{\prime} \mathrm{S} 50^{\circ} 10^{\prime} \mathrm{E}$ ), north-eastern Madagascar, without any supporting evidence. Until further information is available, its occurrence there remains undocumented. 
Table 1. Measurements (in $\mathrm{mm}$ ) of seven museum specimens of Tyto soumagnei.

\begin{tabular}{|c|c|c|c|c|c|c|c|}
\hline $\begin{array}{l}\text { Museum and } \\
\text { number }\end{array}$ & Locality & Sex & $\begin{array}{l}\text { Wing } \\
\text { chord }\end{array}$ & Tail & Tarsus & $\begin{array}{l}\text { Bill from } \\
\text { skull }\end{array}$ & $\begin{array}{l}\text { Bill from } \\
\text { nostril }\end{array}$ \\
\hline $\begin{array}{l}\text { MNHN } \\
1888.640 \text { (type) }\end{array}$ & \multicolumn{6}{|c|}{ MNHN } & - \\
\hline 1932.3795 & Analamazaotra & male & 215 & 93 & 54.3 & 32.9 & 17.7 \\
\hline \multicolumn{8}{|l|}{ BMNH } \\
\hline 1955.6.N.20.4928 & E. Imerina & $?$ & 230 & 99 & 57.2 & 36.0 & 15.9 \\
\hline 1955.6.N.20.4929 & Merimitatra & $?$ & 219 & 99 & 55.6 & 33.5 & 15.0 \\
\hline $1879 \cdot 3 \cdot 5 \cdot 25$ & Antananarivo & $?$ & 215 & 94 & 55.0 & 40.7 & 16.6 \\
\hline \multicolumn{8}{|l|}{ AMNH } \\
\hline 458989 & Forêt de Lakato & male & 222 & 93 & 53.8 & 33.8 & 14.2 \\
\hline \multicolumn{8}{|l|}{ FMNH } \\
\hline 363792 & Andapa & female & $\begin{array}{c}190 \\
\text { (worn) }\end{array}$ & 97 & 58.7 & - & - \\
\hline $\begin{array}{l}\text { Summary statistics } \\
\text { mean } \pm \text { standard } \\
\text { deviation }\end{array}$ & & & $\begin{array}{l}214.4 \\
\pm 12.5\end{array}$ & $\begin{array}{l}94.7 \\
\pm 3.6\end{array}$ & $\begin{array}{l}55.8 \\
\pm 1.9\end{array}$ & $\begin{array}{l}35.4 \\
\pm 2.9\end{array}$ & $\begin{array}{r}15.9 \\
\pm 1.4\end{array}$ \\
\hline
\end{tabular}

Fito A specimen held in the Museum of Comparative Zoology was collected on 15 February 1934 "dans la Forêt Sihanaka, près du village d'Andrandramanita [ $18^{\circ} \mathrm{OI}^{\prime} \mathrm{S} 4_{4}^{\circ}{ }^{\circ} 6^{\prime} \mathrm{E}$ ], route du lac Alaotra, Forêt de l'Est, Région de Fito" by Herschell-Chauvin (MCZ 166930). This is the specimen discussed by Allen and Greenway (1935).

Forêt Sihanaka Delacour (1932) reported that three specimens of $T$. soumagnei were collected in the Forêt Sihanaka. Lavauden (1932) further noted that of these three specimens one was housed in the Muséum de Tananarive (almost certainly the specimen currently on exhibit at l'Académie Malgache, Antananarivo) and two held by Herschell-Chauvin were destroyed in 1927 during a cyclone that devastated Toamasina. Herschell-Chauvin was an active collector based in Antananarivo who made field trips to the forests near Fito and Didy $\left(18^{\circ} \mathrm{O} 7^{\prime} \mathrm{S}\right.$ $48^{\circ} 32^{\prime} \mathrm{E}$ ). The data tags of numerous Herschell-Chauvin bird specimens are labelled "Didy, Forêt Sihanaka" or "Fito, Forêt Sihanaka". Thus, we assume that his specimens labelled "Forêt Sihanaka" are from the general Didy and Fito area, a large forest block south-east of Lake Alaotra and south of the Réserve Naturelle Intégrale de Zahamena. Rand (1936), who had contact with Herschell-Chauvin, clearly stated that the localities of Fito and Didy were part of the Forêt Sihanaka. Viette (1991) and Wilmé (1994) have defined the Forêt Sihanaka (= Antsianaka or Antsihanaka) as the region to the east of Lac Alaotra.

Fierenana In March 1973, while exploring relatively undisturbed rainforest along the Ranofotsy River, near Fierenana $\left(18^{\circ} 28^{\prime} S 4^{\circ} 24^{\prime} \mathrm{E}\right)$, P. Calabi and J. Pollock observed an owl. This record has previously been accepted as a Madagascar Red Owl (King 1978-1979) and subsequently reiterated by numerous reviewers (Collar and Stuart 1985). A. Forbes-Watson and O. Langrand kindly allowed us to examine the original correspondence between P. Calabi and A. Forbes-Watson concerning this record. In a letter dated 20 August 1973, P. Calabi states "Though I do not have a copy of my field notes on the soumagnei, here is the pertinent jrurnal entry, with some background description. 17/3/73-Fierenana 1300 metres. Montane rainforest, essentially undisturbed, 8:30 pm, cool, drizzley. 'The owl was 
lovely - tawny gold-brown. 10-12" (tall) with smooth round face and dark eyes and quite close to two microcebus at 5-6 m.' " A map attached to the letter pinpoints the exact locality. The Ranofotsy River is about $40 \mathrm{~km}$ south-west of Didy and part of the continuous Forêt Sihanaka (as defined above) and $50 \mathrm{~km}$ north of Analamazaotra. J. Pollock (pers. comm.) has verified these details. Although the description provided by Calabi is somewhat imprecise, we believe that it accurately describes the distinctive coloration and size of Tyto soumagnei.

Near Tamatave [=Toamasina] The type specimen held by the Muséum National d'Histoire Naturelle (MNHN), Paris, was collected in 1876 "sur la côte orientale de Madagascar, non loin de Tamatave" by M. Soumagne, "consul honoraire de France à Tamatave" (Grandidier 1878, MNHN 1888.640).

Merimitatra A specimen housed in the Natural History Museum, Tring (BMNH 1955.6.N.20.4929), was collected in January 1895 at Merimitatra by J. Wills. Collar and Stuart (1985) have interpreted this locality as probably east of Anjozorabe (approx. $18^{\circ} 25^{\prime} \mathrm{S} 48^{\circ} \mathrm{O} 5^{\prime} \mathrm{E}$ ).

Analamazaotra Lavauden (1932: 636) reported that two specimens were collected "non loin de la Maison forestière d'Analamazaotra, par le brigadier forestière Thouvenot". These include an adult male in January 1930 and a second adult male in March 1930 (Lavauden 1932, Langrand 1985). The later specimen is held in the Paris Museum (MNHN 1932.3795). This site is near to or within the Réserve Spéciale d'Analamazaotra (formerly called Périnet).

Near Antananarivo A specimen (BMNH 79.3.5.25) collected "in the neighbourhood of Antananarivo" was received by the museum in 1879 (Sharpe 1879). This locality is ambiguous and we are hesitant to accept the record as evidence of the species's occurrence in the central portion of the high plateau. The plumage coloration of this specimen is distinctly darker and more rufous, particularly the ventrum, than the other specimens of this taxon we have examined.

Eastern Imerina A specimen bearing the locality "Forest: E[astern] Imerina" was taken in March 1893 by Wills (BMNH 1955.6.N.20.4928). The Imerina is a cultural group living in the central portion of the high plateau, so the owl was presumably taken in the eastern portion of the central high plateau. This is a large area and in the late nineteenth century contained considerable areas of intact forest, including the known sites of Analamazaotra and Fito.

Forêt de Lakato A specimen held in the American Museum of Natural History (AMNH 458989 ) was taken in January 1895 in the Forêt de Lakato $\left(19^{\circ} 18^{\prime} \mathrm{S}\right.$ $48^{\circ} 29^{\prime} \mathrm{E}$ ), about $30 \mathrm{~km}$ south of Analamazaotra.

On the basis of documented records, the northern limit of the Madagascar Red Owl is Andrandramanita, just north of Fito, and the southern limit is Foret de Lakato. Over the past 50 years there has been considerable zoological work conducted on the island and except for the sight record near Fierenana there has been no evidence of the continued existence of this species. The FrancoAnglo-Américaine mission undertaken between 1929 and 1931 did not find it (Rand 1936), despite 16 months of extensive work in different natural habitats of Madagascar. Further, the Réserve Spéciale d'Analamazaotra is one of the most frequently visited forest sites on the island by birdwatchers, yet there have been no subsequent records of this species in or in close proximity to the reserve since 1930 . 


\section{The rediscovery}

In the context of a conservation development project of WWF in the Réserve Spéciale d'Anjanaharibe-Sud and Réserve Naturelle Intégrale de Marojejy in north-eastern Madagascar, D.H. is stationed in Andapa. On 26 July 1993 he was contacted by a local person about a captive bird held in the town. On examination the bird proved to be a Madagascar Red Owl. The discovery of a captive Madagascar Red Owl in Andapa is the first physical evidence of this species's existence in over 60 years. Further, the locality is about $475 \mathrm{~km}$ north of the previously documented northernmost point of its range.

The plumage coloration and external morphology of the captive bird fits previously published descriptions (Grandidier 1878, Milne Edwards and Grandidier 1879, Langrand 1990; see Table 1). In general it looked like a small orange Barn Owl Tyto alba. When perching, the wings were slightly longer than the tail.

When D.H. found the owl it had already been in captivity for about one year and was in poor health. According to its keeper, it had been captured in a forest located south-west of Andapa, near the village of Antanamangotroka at approximately $800 \mathrm{~m}$ altitude $\left(14^{\circ} 43^{\prime} \mathrm{S} 49^{\circ} 4 \mathrm{o}^{\prime} \mathrm{E}\right)$. This site is connected by a forested corridor to the Réserve Spéciale d'Anjanaharibe-Sud. The lowland forest of Anjanaharibe-Sud is classified as rainforest of the Eastern Domain (Nicoll and Langrand 1989).

Before the owl was transferred to D.H.'s care in late July 1993, it had been fed beef, frogs, rats and grasshoppers. Thereafter, on the basis of information in the literature concerning the Madagascar Red Owl's natural diet (Lavauden 1932), it was mostly given frogs - which it readily ate. It was fed twice per day, at dawn and dusk. The bird was only attracted to moving prey. In cases when the prey was dispatched by the owl and then dropped on to the floor of the cage, even within a few $\mathrm{cm}$ of the bird, the prey was not relocated. After catching frogs, the owl would hold the prey in its talons and crush the skull with its bill. After the frog was dead or immobile, the owl grasped it in its talons to crush the prey's bones. When the prey was large, greater than $6-7 \mathrm{~cm}$, the owl would first remove and eat the head, and thereafter consume the rest of the body. A mouse given to it was eaten in the same manner. A live cockroach was disregarded by the owl. Pellets were dark grey and about $3.5 \mathrm{~cm} \times 2.0 \mathrm{~cm}$, usually regurgitated 18 to 20 hours after feeding; and largely composed of bones.

The bird was heard to vocalize only a few times. It uttered a distinct hissing sound similar to the Barn Owl, although perhaps slightly higher-pitched. No other vocalization was given.

It is difficult to know if the owl's response to prey and its behaviour patterns in general were normal or the result of modification in captivity. Further, the general condition of the bird declined during the period it was held by D.H. as a result of previous injuries. The bird appeared to suffer from partial paralysis associated with a neurological disorder, and, further, several osteological deformities manifested themselves. The bird died in December 1993, and was saved as a partial skin/skeleton which is housed in the Field Museum of Natural History (FMNH 363792), Chicago. Fresh tissue samples were also saved in a buffered DNA preservative. The animal was an adult female, which on autopsy had no enlarged ovarian follicles. It was slightly emaciated and weighed $245 \mathrm{~g}$. 


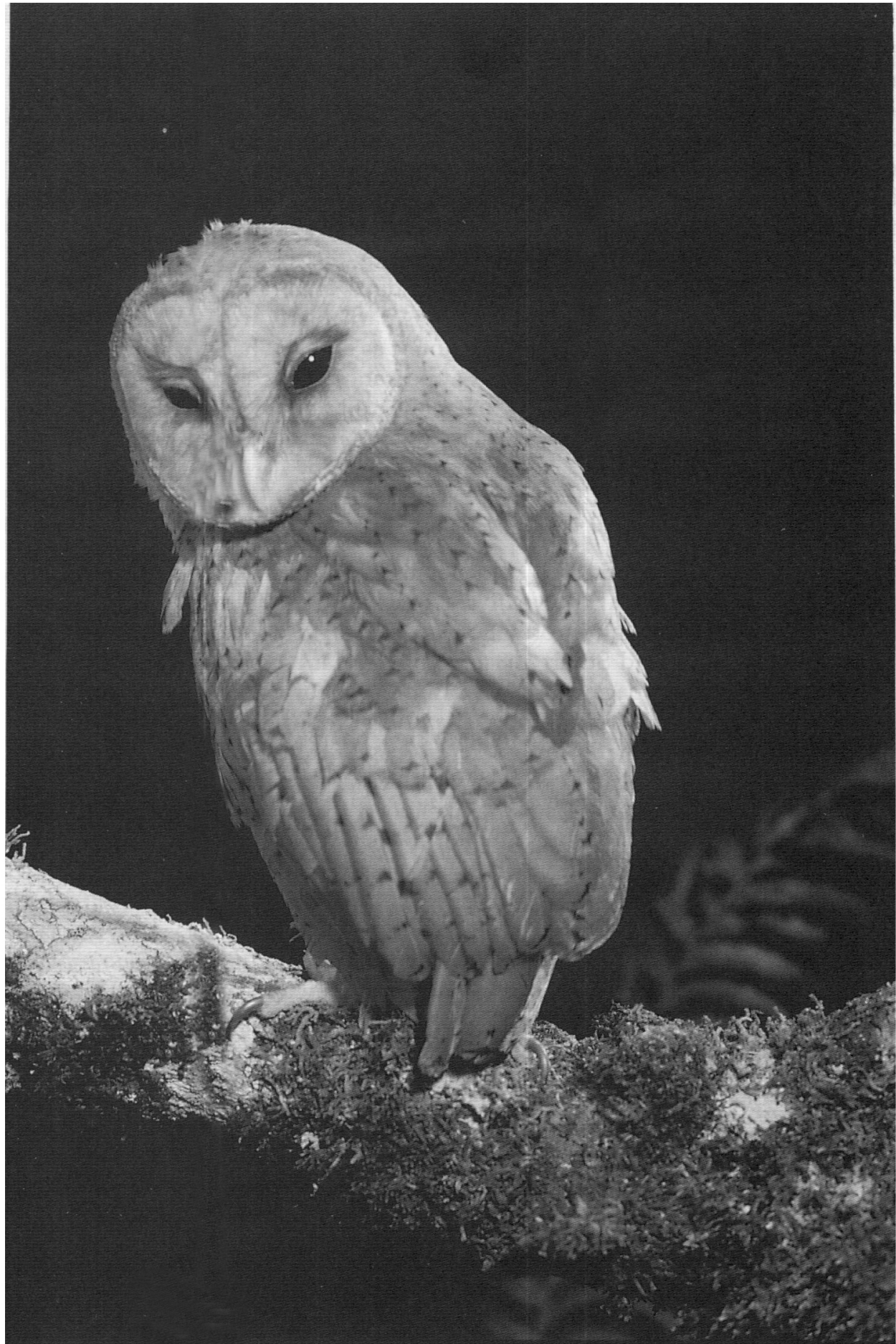

Figure 1. Madagascar Red Owl Tyto soumagnei in captivity. This is the individual obtained close to the village of Antanamangotroka, near Andapa. (Photo: D. Halleux.) 
According to some villagers around the Anjanaharibe-Sud reserve, the Madagascar Red Owl inhabits the forest and is only occasionally observed, generally as single individuals. One of the reported local Malagasy names for this species was hankanabalotra: hankana is generally the name of the Madagascar Long-eared Owl Asio madagascariensis, and valotra the name of a canopy tree, Nauclea cuspidata (family Rubiaceae). The association between the owl and this tree is not clear. The second name reported is vorondolo mena, meaning "red owl". Vorondolo is generally the name associated with the Barn Owl. The informants are unfamiliar with this species's nest.

Owls are generally considered in the Andapa area, and in many places on Madagascar, as witches or sorcerers. This is particularly true for the Barn Owl, which would not normally be kept in a house as a pet. What is curious, though, is that given the similarity in general appearance and colour of the Barn Owl and the Madagascar Red Owl and that they are both vorondolo, there seems to be no taboo in the Andapa case in keeping the latter in captivity.

\section{Conservation status}

Following the IUCN criteria, the Madagascar Red Owl is listed as "Indeterminate", which means "taxa known to be Endangered, Vulnerable or Rare but where there is not enough information to say which of the three categories is appropriate" (Collar and Stuart 1985: XXv). Malagasy national legislation gives full protection to this species. It is classified in Appendix I of the CITES treaty, to which Madagascar is a signatory. The record reported herein from Andapa does not provide information to make any significant change in the status of this species, although it is now clear that it has a much broader range than previously known. This increases the likelihood that other populations exist in poorly known areas of rainforest in north-eastern Madagascar. Several other endemic birds that were thought to be extremely rare have been rediscovered in the past few years. These include the Madagascar Serpent-eagle Eutriorchis astur (Sheldon and Duckworth 1990, Raxworthy and Colston 1992), Madagascar Pochard Aythya innotata (Wilmé 1993), Slender-billed Flufftail Sarothura watersi (Wilmé and Langrand 1990) and Red-tailed Newtonia Newtonia fanovanae (Goodman and Schulenberg 1991, Evans 1991). These findings are in part a result of increased ornithological activity on the island and excursions in areas of large and previously unexplored areas of forest.

\section{Acknowledgements}

We are grateful to A. D. Forbes-Watson for sending to $O$. Langrand the correspondence concerning the 1973 record. M. LeCroy, American Museum of Natural History, New York, R. P. Prŷs-Jones, British Museum (Natural History), Tring, R. A. Paynter, Jr., Museum of Comparative Zoology, Cambridge, and J.-F. Voisin, Muséum National d'Histoire Naturelle, Paris, kindly made specimens available for examination. O. Langrand provided important comments on a previous version of this paper, and translated the summary into French. 


\section{References}

Allen, G. M. and Greenway, J. (1935) A specimen of Tyto (Heliodius) soumagnii. Auk 52: 414-417.

Collar, N. J. and Stuart, S. N. (1985) Threatened birds of Africa and related islands. Cambridge, U.K.: International Council for Bird Preservation.

Delacour, J. (1932) Les oiseaux de la mission zoologique Franco-Anglo-Américaine à Madagascar. Oiseau et R.F.O. 2: 1-96.

Evans, M. I. (1991) The Red-tailed Newtonia Newtonia fanovanae in the Ambatovaky Reserve, north-east Madagascar. Bird Conserv. Internatn. 1: 47-52.

Goodman, S. M. and Schulenberg, T. S. (1991) The rediscovery of the Red-tailed Newtonia Newtonia fanovanae in south-eastern Madagascar with notes on the natural history of the genus Newtonia. Bird Conserv. Internatn. 1: 33-44.

Grandidier, A. (1878) Note sur un nouveau Strigidé de Madagascar. Bull. Soc. Philomat., Paris, (7) 2 (for 1877-1878): 65-66.

King, W. B. (1978-1979) Red Data Book, 2: Aves. Second edition. Morges, Switzerland.

Langrand, $O$. (1985) Inventaire et étude de la collection d'oiseaux de Madagascar conservée au Muséum d'Histoire Naturelle de Grenoble. Grenoble: Muséum d'Histoire Naturelle.

Langrand, O. (1990) Guide to the birds of Madagascar. New Haven: Yale University Press.

Lavauden, L. (1932) Etude d'une petite collection d'oiseaux de Madagascar. Bull. Mus. Natn. Hist. Nat. (2) 4: 629-640.

Milne Edwards, A. and Grandidier, A. (1879) Histoire physique, naturelle et politique de Madagascar, 12. Histoire naturelle des oiseaux. Tome 1, text. Paris: Imprimerie Nationale.

Milon, P., Petter, J.-J. and Randrianasolo, G. (1973) Faune de Madagascar, 35: Oiseaux. Antananarivo and Paris, ORSTOM/CNRS.

Nicoll, M. E. and Langrand, O. (1989) Madagascar: revue de la conservation et des aires protégées. Gland, Switzerland: World Wide Fund for Nature.

Rand, A. L. (1936) The distribution and habits of Madagascar birds. Bull. Amer. Mus. Nat. Hist. 72: 143-499.

Raxworthy, C. J. and Colston, P. R. (1992) Conclusive evidence for the continuing existence of the Madagascar Serpent-eagle Eutriorchis astur. Bull. Brit. Orn. Club 112: 108-111.

Sharpe, R. B. (1879) A note on Heliodilus soumagnii, Grandidier. Proc. Zool. Soc. London: 175-176.

Sheldon, B. C. and Duckworth, J. W. (1990) Rediscovery of the Madagascar Serpent-eagle Eutriorchis astur. Bull. Brit. Orn. Club 110: 126-130.

Viette, P. (1991) Faune de Madagascar. Principales localités où des insectes ont été recueillis à Madagascar. Supplément 2. Published by the author.

Wilmé, L. (1993) A recent record of the rare Madagascar pochard Aythya innotata on Lake Alaotra, Madagascar. Bull. Brit. Orn. Club 113: 188-189.

Wilmé, L. (1994) Status, distribution and conservation of two Madagascar bird species endemic to Lake Alaotra: Delacour's Grebe Tachybaptus rufolavatus and Madagascar Pochard Aythya innotata. Biol. Conserv. 69: 15-21.

Wilmé, L. and Langrand, O. (1990) Rediscovery of Slender-billed Flufftail Sarothura watersi (Bartlett, 1879), and notes on the genus Sarothura in Madagascar. Biol. Conserv. 51: 211-223.

DOMINIQUE HALLEUX

WWF Aires Protégées, B.P. 738, Antananarivo (101), Madagascar

STEVEN M. GOODMAN

Field Museum of Natural History, Roosevelt Road at Lake Shore Drive, Chicago, Illinois 60605, U.S.A. Present address: WWF Aires Protégées, B.P. 738, Antananarivo (101), Madagascar 